\title{
Exploring Factors of the Sustainable Supply Chain in the Post-COVID-19 Pandemic: SWARA Approach
}

KHIZAR HAYAT ( $\sim$ khizarhayat@nuaa.edu.cn )

Nanjing University of Aeronautics and Astronautics College of Economics and Management

ZHU JIANJUN

Nanjing University of Aeronautics and Astronautics

Sharafat Ali

Government Graduate College Kot Sultan, Layyah, Punjab, Pakistan

Muhammad Adeel Khan

Bahauddin Zakariya University

\section{Research Article}

Keywords: Sustainable supply chains, survivability, Post-COVID-19, viability, digital data-driven supply chains, buyer-supplier relationship

Posted Date: June 28th, 2021

DOI: https://doi.org/10.21203/rs.3.rs-561684/v1

License: () (1) This work is licensed under a Creative Commons Attribution 4.0 International License. Read Full License 


\section{Abstract}

The present research aimed to provide a mechanism for enhancing sustainable supply chain survivability during and after the COVID-19 outbreak. The working system for firms and employees has been restricted worldwide due to the COVID-19 pandemic, including working on-sites, different areas, and working hours. Therefore, the system changed into a network economy to reduce unemployment and increase the work opportunities for workers. As a result, businesses are now attempting to improve the system for sustainable supply chains. The Stepwise Weight Assessment Ratio Analysis (SWARA) approach is used in this research to classify dynamic aspects for improving the survival of sustainable supply chains in an epidemic condition. The results reveal that the viability of the supply chain network is the essential criteria for managing the relationships of suppliers and buyers and maximizing sustainable supply chain survivability during and after COVID-19. This research will help businesses, manufacturers, and other stakeholders to concentrate on the described factors to achieve a brighter environment.

\section{Introduction}

Demand-supply distraction is influencing supply chains all over the world. Coronavirus (COVID-19) outbreaks have had a significant impact on the global and local economies. As a result, supply access has been limited and unbalanced with the growing demand for critical products for daily life. Many risk factors are overwhelming, but resiliency in the supply systems can be established quickly (Ivanov 2020). COVID-19 cases have been steadily rising in Europe, Asia, and United States since early February 2020. Now, India is in very tough condition due to an uncontrollable wave of the virus (Thiagarajan 2021). Because of unlimited positive cases, the oxygen demand increased, which caused the oxygen crisis. These conditions result in lockdowns, border controls, quarantine, and a significant reduction the foreign trade, with declines ranging from 12 percent to 33 percent (WTO 2020). The majority of the supply chain network has capitulated to this unmanageable virus (Araz et al. 2020). The outflow of a virus in the world is determined by many countries infected and the extent of time that lockout procedures are expected. The most significant factor of global expense is the pandemic's geographic extent (Guan et al. 2020). The supply chain in all the sectors has been affected due to COVID-19 and also has had a long-term effect on societies and populations. COVID-19 has a significant direct impact on supply chains in the clothing, jewelry, shoes, electronics, and technological industries (Fortune 2020). One thousand fortune companies have been influenced due to COVID -19 (Mckin-sey 2020). According to the Resiliency pattern, globally, the top 1000 supply chains have over 12,100 services in the isolation regions. (Linton and Vakil 2020; Ivanov and Dolgui 2020). Dun and Bradstreet (2020) describe direct suppliers of 51,000 companies and indirect suppliers of five million companies in the Wuhan city of China. The working style of traditional workers has been changed due to COVID-19; however, the supply chain companies are trying to shift to secure areas where life will be accessible in both working time and earning money. Concerning corporate social responsibilities with limited and flexible time, Companies could effectively perform the social responsibilities.

Global sustainability encourages firms to redesign and reform economic, social, and environmental concerns for maintaining the buyer-supplier relationship by mutual coordination ( $\mathrm{Ni}$ and Sun 2018). Sustainability and coordination of suppliers are critically crucial for building customer relationships to have sustainable outcomes (Badraoui et al. 2020; Alghababsheh and Gallear 2020; Reuter et al. 2010; Alghababsheh and Gallear 2020). Due to the rise of the coronavirus, a life-threatening environment exists all over the globe, imposing specific legislation, strict safety regulations, crowded places of public, and limited working time have placed an enormous pressure on businesses' stakeholders, governments, and policymakers to maintain their supply chains with economic, environmental and economic factors (Cohen 2020; Sarkis et al. 2020). An epidemic has generated difficulties and marathon fights for businesses thriving in the market environment how long-term outcomes could be provided in the presence of an epidemic. The demand-supply mechanism has been severely affected because of the rise in demand for sanitizers, gloves, masks, disinfectants, and the availability of these products, which has become unsustainable, putting the supply chains survivability and sustainability at risk across all coronavirus affected regions. Global supply chains have a complicated composition since they are made up of several different entities spread around many other places. The gap between customers and retailers creates challenges in dealing with sustainability (Blackhurst et al. 2011). The conventional approach to supply chains is no longer relevant in the current environment, requiring the development of new supply chains to stay competitive, viable, and linked to consumers in the long run (Albors-Garrigos 2020). Supply chains must evaluate the market, predict customer needs in lockdowns, and work collaboratively with local retailers to ensure quality service. However, the most important considerations on which supply chains can concentrate to achieve survivability and survival during pandemics remains unanswered. The following empirical questions must be addressed by qualitative research. Which variable plays a vital role in improving the sustainable supply chain survivability in post-COVID-19 scenarios? During COVID-19 outbreaks, how is the buyer-supplier partnership managed? What do supply chains rely on to survive in the post-COVID-19 for the long term? The study intends to look at and analyze the elements that affect sustainable supply chain survivability during post-COVID-19. Thus, a thorough analysis is carried out, and the following research priorities are set in.

Fast-moving consumer products and a portion of resilient food and healthcare supply chain are among the key elements. After COVID-19, the existing global supply chain limitations were revealed, resulting in sales reduction, production, and supply unfulfillment. The condition serves as a lesson in supply chain resilience and durability in the context of a declining economy. In this respect, a thorough examination of the current crisis and the required steps must be illustrated. The COVID-19 epidemic has had significant effects on the supply chain, and the repercussions of the global sustainable supply chain are expected to be severe in the first quarter of 2021. It emphasizes the importance of a resilient supply chain and tries novel approaches to long-term supply chain recovery. The logistics infrastructure is important for handling supply chain disturbances and stabilization and ensuring supply chain sustainability. As a result, we incorporated factors from various studies and applied the SWARA method for weight measurement, which was never explored before. Many factors influence the supply chain's buyer-supplier relationships, including distribution channels, supplier appraisal, supplier cooperation, efficiency, business value, coordination, and data security (Kumar 2019; Kumar and Rahman 2016). As a result, businesses must create sustainable supply chains that consider the social environment, consumer expectations, and the quality of national distributors to fulfill orders without losing people who manage the buyer-supplier alliance. The Multi-Criteria Decision-Making (MCDM) - Stepwise Weight Assessment Ratio Analysis (SWARA) approach is used in this research. SWARA has significant capabilities over other weighting tools; it can estimate experts' opinions about the importance ratio of criteria in the weighting process. SWARA is useful for managing and collecting data from experts. It is easy, friendly users, transparent, and analysts can conveniently collaborate. An advantage of this 
approach is that it calculates issue preferences depending on company policy. As a result, no need to rank the parameters first. SWARA gives stakeholders the ability to make choices depending on various scenarios and evaluate parameters based on their specific priorities and objectives.

The SWARA approach assists in determining the factors that contribute to long-term supply chain sustainability (Karabasevic et al. 2016). According to Wang et al. (2019), this approach uses to compute the relative/comparative weight coefficients that provide accurate outcomes in the analysis for a better decision. This research is helpful to understanding the factors that contribute to developing long-term supply chains during the post- COVID-19 pandemic. This study adds to the knowledge of the core considerations that must be weighed to sustain an efficient buyer-supplier relationship and increase the survival of supply chains sustainability. The study would help organizations in controlling their supply chains to maintain in a pandemic. Our study subsidizes to the academic literature and delivers appropriate insights to companies as well. Prior research did not extent a consensus on the effectiveness of sustainable supply chains. Whereas some theoretical arguments and empirical results recommend that sustainable supply chain is necessary in post COVID situation.

Section 2 of this paper outlines the literature review and theoretical framework used in this study. Section 3 discusses the research framework, section 4 discusses the research methodology. Section 5 highlights the results and discusses the findings section 6 presents the conclusion and implications.

\section{Literature Review}

\subsection{Factors for sustainable supply chains}

The interaction of supply chain and environmental growth is the sustainable supply chain. Manage their relations with distributors involves environmental, economic, and social concerns (Dubey et al. 2017). Organizations are moving to a demand-driven paradigm for handling their supply chains in the event of a pandemic (Chi et al. 2020; Choi and Guo 2020). COVID-19 has put a lot of emphasis on organizations offering both tangible and intangible resources, so they're using new types of supply chains to do so. To meet demand and supply, the firms consider outsourcing middle man and depend on the supply chain system's association with multiple single-level suppliers (Wilhelm et al. 2016). Global supply chains use both traditional and non-digital modes to expand their presence and remain competitive in the industry (Araz et al. 2020). The supply chain's controlled inventory gives the distributor access to actual inventory data, forecasting, and order specifics, which helps the upstream distributor (Prince et al. 2019). Additional platforms, associations, value-adding, co-creation, optimization techniques of distribution and pickup options, Omnichannel supply chains, balancing management capacity, order fulfillment, embracing digital applications, and crowd and capital management are all areas where the supply chains are focused (Mckinsey 2020). Studies show that a firm's organizational structure is based on teamwork when it comes to knowledge exchange. Because of the volatile situation, the supply chains have been encouraged to work with various collaborators to minimize the ambiguity and reduce risk (Li and Jiang 2019; Madsen and Petermans 2020; Hughes et al. 2019).

The supply chain's efficiency has improved due to the collaboration, which has reduced costs and improved profitability. The bullwhip effect in supply chains can be reduced by retailers and suppliers working together (Dolgui et al. 2020). The supply chains come in various shapes and sizes, but they all help alleviate the distress of the affected people. Both physical and intellectual assets are widely shared, and these resources and knowledge exchange are critical for successful communication between suppliers and buyers (Pankowska 2019). Supply chain exposure to disruptions has been examined in previous research studies in the physical aspect, uncertainty considerations, and conceptual network analysis (Ivanov et al. 2010; Pavlov et al. 2019; Li and Zobel 2020). Its conservation focus and environment orientation calculate the longevity of a system. The feasibility of supply chains combines efficiency and durability and adds durability to the process (Ivanov and Dolgui 2020). From the available literature, essential elements for improving the buyer-supplier relationships and survival of sustainable supply chains are created. The procedure is divided into the following five stages: (I) defining study aim and intentions; (II) keyword classification; (III) database selection; (IV) variety of research papers and (V) analysis of data.

Researches have investigated supply chain challenges, restrictions, channels, sharing of knowledge, convergence, and supplier engagement (Marques 2019; Silvestre et al. 2020; Liu and Lee 2018; Nazam et al. 2020); coordination (Wankmüller and Reiner 2020); order fulfillment and Delivery supply chains (Ishfaq and Raja 2018); Strength and longevity in provider relationships (Touboulic et al. 2014); supply chain management competition (Tidy et al. 2016; Sauer and Seuring 2017; Patel and Desai 2019); Model growth in supply chain management (Brandenburg et al. 2019) as well as stability and buyer-supplier relationships (Kumar and Rahman 2016). The existing studies have examined supply chain challenges. Still, there has been no systematic analysis of the requisite significant factors for improving sustainable supply chains during pandemics, specifically in the post-COVID-19 context. As a result, this research fills in the gaps. It examines the drivers to give additional insights to supply chains about reinventing their sustainability of supply chains to succeed during and post-COVID-19 scenarios.

The questions are presented for sustainable supply chains and the buyer-supplier partnership, followed by a database including 'Web of Science' (WoS) and 'Scopus.' The phrases supply chain and sustainability of supply chain, supplier relationship or resiliency, or supplier's network are used to finding the keywords. The terms must appear in the abstract, names, and keywords-the paper considered between the times of 2012 to 2021 in the study. In the first search found 378 papers from the web of science and 640 Scopus papers. After the removal of copied from the papers, 910 research papers according to the research questions are listed. Conference papers, presentations, and working papers did not include, so only published in journals were included for review. After excluding the unrelated pieces, a total of 201 research papers are listed. A total of 39 papers are picked up after the complete screening. Factors for improving supply chain survivability and buyer-supplier relationships are built from the listed articles. Each professional must review the data sheet with the questionnaire carefully and assess each factor (Appendix A). In Section 3.2, expert information is given. Experts evaluate these elements based on six key parameters - Criteria 1 (Crt1): Supply Chain Performance in uncertain conditions; Criteria 2 (Crt2): Configuration of Supply-Chain (CSC); Criteria 3 (Crt3): governance of supply chain (GSC); Criteria 4 (Crt4): Viability of network of the supply chain (VSC); Criteria 5 (Crt5): Collaborations of the supply chain; Criteria (6) (Crt6) digital data-driven of the supply chain. There are sub-criteria for each criterion. Table 1 shows the final representation of the primary and subcriteria. 
This has tried to engage with the infected supply chains as a result of coronavirus outbreaks.

The research assists in identifying conditions that contribute to the long-term viability of sustainable supply chains and the handling of buyer-supplier relationships. The study guides companies, retailers, government agencies, and professionals about handling their supply chains to meet society's social and economic needs while not losing business in the epidemic. For determining the significant factors to survive in a COVID-19 scenario, the analysis used the advanced MCDM approach SWARA (stepwise weight assessment ratio analysis). Because MCDM is the hub of decision making approaches (Ikram et al. 2020). This research involves defining variables to design and operate sustainable supply chains for fast-moving consumer goods companies in the unpredictable world of an epidemic (coronavirus) as a distinctive character. It sheds light on the feasibility and resiliency of supply chains. It can prompt them to modify their current tactics to improve their resiliency in both pre-and post-pandemic scenarios.

\section{Proposed Research Framework}

To accomplish the research goals, the structure involves a three-step mechanism. In the first step, a comprehensive literature review is used to identify the variables needed to improve sustainable supply chain survivability and fair relations between suppliers and buyers in the COVID-19 epidemic. The confirmation of elements and exploration using the SWARA tool for weight calculation is included in the second stage. The critical reasons for handling sustainable supply chain and supplier relationships are defined and addressed after the weights have been determined in the third stage. Figure 01 demonstrates the anticipated study configuration.

\subsection{Propose framework application}

The research's primary focus is building sustainable supply chains and maintaining buyer-supplier relationships in the post-COVID situation. The study has taken 18 experts with the same expertise, skills, and resources for data collection. The supply chain must check in the changing world and, based on the results to take constructive measures for better outcomes. Three managers from the manufacturing and procurement divisions are also among the specialists. The two managers from the sales department have been tasked with considering demand and sales dynamism. Manufacturers, retailers, and suppliers are also considered specialists in understanding the downstream supply chain. Two shipment exectives are comprised in the advisory group for logistical input. The supply chains have been working with the manufacturers, dealers, and sellers in the expert panel for more than ten years. Demand and supply, procurement, manufacturing, client associations, order fulfillment, shipping, logistics, and sales are all managed by the selected supply chain

practitioners. The experts' expertise ranges from 10 to 15 years. The experts are mailed the extensive details about all of the elements and the questionnaire for their answers (Table A1). The factors and sources for measuring the sustainability are given in the table 1.

Table 1. Elements of sustainable supply chain's survival for (post-COVID-19) situation. 
Criteria

Crt1-Supply chain performance in

uncertain

conditions
Factors

efficiency in economic output

(Crt1-01)

efficiency in

social

interactions

(Crt1-02)

Environmentally

sustainable

output (Crt1-03)

Crt2- Configuration

of Supply-Chain

supply chain in

the traditional

way (Crt2-01)
Descriptions

Focused on the accounting, methods, and market environment
Expected sustainable outcomes

Integration of cost-saving methods for suppliers
References

Leszczynska

(2018); Blome et al

(2014); Gereffi and Lee

(2016)

Civil rights, work conditions, employee protection, environmenta health, and safety features are all taken into account

Effective utilization of reusing, waste management, and resource

buyer only linked with single-tie supplier
Social responsibility policies, such as binding to labor force rules and ethical norms, are being adopted

Environmental science schemes and sustainable business methods are being adopted.

Concentrate on ensuring the long-term viability of direct suppliers.
Harms et al. (2013)

Yawar and Seuring

(2017); Ashby et al. (2012)

Lintukangas et al.

(2015); Tidy et al.

(2016); Ni and Sun

2018); Merminod and

Paché (2011)

Nakano and
Matsuyama (2020); Tachizawa and Wong (2014)

$\begin{array}{ll}\begin{array}{l}\text { Dynamic supply } \\ \text { chain }\end{array} & \text { Supply } \\ \text { (Crt2-02) } & \text { chains links with multi-tier supplier }\end{array}$

Sustainability can be extended to multi-tier distributors of focal companies.

Wilhelm et al. (2016)

Dania et al.

(2019); Kudla et al. (2012)

The supply chain Non-economic stakeholders are that seems to be used for the supply chain.

closed (Crt2-03)
Non-economic factors, such as NGOs, can collaborate with purchasing firms (third parties). Improved upstream sustainability results through formal and informal cooperation
Roy et al.

2018): Wilhelm et al. (2016)

\begin{tabular}{|c|c|c|}
\hline $\begin{array}{l}\text { Crt3- governance } \\
\text { of supply chain }\end{array}$ & $\begin{array}{l}\text { Improved the } \\
\text { supplier's skills } \\
\text { (Crt3-01) }\end{array}$ & $\begin{array}{l}\text { Suppliers receive instruction and } \\
\text { assistance from the financial } \\
\text { institution. }\end{array}$ \\
\hline & $\begin{array}{l}\text { Action for multi- } \\
\text { stakeholder (Crt3- } \\
02 \text { ) }\end{array}$ & $\begin{array}{l}\text { Partnerships with other firms, } \\
\text { including specific associations a } \\
\text { the state, etc. }\end{array}$ \\
\hline & $\begin{array}{l}\text { Initiatives for } \\
\text { Third-party (Crt3- } \\
\text { 03) }\end{array}$ & $\begin{array}{l}\text { The collaborative effort with } \\
\text { stakeholders }\end{array}$ \\
\hline \multirow{3}{*}{$\begin{array}{l}\text { Crt4- Viability of } \\
\text { supply chain } \\
\text { network }\end{array}$} & $\begin{array}{l}\text { Resilience (Crt4- } \\
01)\end{array}$ & $\begin{array}{l}\text { Able to restore results after being } \\
\text { disrupted }\end{array}$ \\
\hline & $\begin{array}{l}\text { Robustness in } \\
\text { supply chain } \\
\text { network (Crt4-02) }\end{array}$ & $\begin{array}{l}\text { Ability to control expected succe } \\
\text { after a disturbance }\end{array}$ \\
\hline & $\begin{array}{l}\text { Stability in } \\
\text { supply chain } \\
\text { network (Crt4-03) }\end{array}$ & $\begin{array}{l}\text { Capacity to revert to something I } \\
\text { a pre-disturbance condition }\end{array}$ \\
\hline \multirow[t]{2}{*}{$\begin{array}{l}\text { Crt5- } \\
\text { Collaborations of } \\
\text { supply chain }\end{array}$} & $\begin{array}{l}\text { Forecasting, } \\
\text { preparation, and } \\
\text { replenishment in } \\
\text { collaboration. } \\
\text { (Crt5-01) }\end{array}$ & $\begin{array}{l}\text { Cooperation with manufacturers } \\
\text { predict unexpected demands by } \\
\text { structured preparation. }\end{array}$ \\
\hline & $\begin{array}{l}\text { Interior } \\
\text { coordination } \\
(\text { Crt5-02) }\end{array}$ & $\begin{array}{l}\text { It assists inside the exchange, } \\
\text { incorporation, and versatility of } \\
\text { content. }\end{array}$ \\
\hline
\end{tabular}

Improve supplier capability or efficiency in terms of financial, environmental, and personal priorities.
Marques (2019); Busse (2016)
To maintain coordination with public organizations to achieve long-term stability

To execute cross-industry cooperation to achieve long-term results

In epidemics, manages distribution network processes to achieve social or economic targets.

To increase production in changing circumstances or epidemics while still bringing financial advantages.

To meet the demands of an ever-changing world

During epidemics, the producer and consumer equilibrium can provide public welfare.
Liu and Lee (2018) Aßländer et al. (2016)

Reinecke et al. (2012)

Hosseini et al. (2019) Carvalho et al. (2012); Adobor (2019)

Simchi-Levi et al. (2018)

Demirel et al. (2019)

Panahifar and Shokouhyar (2019);

Holgado de Frutos et al. (2020); Hollmann et al. (2015)
Sharing of information improves the value chain as well as the collection of critical distribution networks.
Kumar (2019); Bodi-

Schubert (2014);

Touboulic and

Walker (2015) Pakdeechoho and

Sukhotu (2018)

Eggers et al. (2017);

Chakraborty et al. (2018); Chen et al. (2017)

Feizabadi et al (2019); Wu et al. (2017)
Competitive edge in supply chain
Abilities help companies achieve a strong position. During pandemics, the supply chain can help reduce
To support humanity by offering fair prices, goods, and new approaches to do so.
Increase in the supply chain's value creation 
Crt6- Supply chain digital data-driven

Just in

time delivery

(JIT) /Order

fulfillment

(Crt6-01)
Supply chains are putting pressure on the local stakeholders to collaborate on item pickup and distribution.
Delivering orders on schedule with the help of digital data analytics saves money and energy.
Ishfaq and Bajwa

(2019); Rao et al. (2011); Ishfaq

and Raja (2018)
Industry 4.0, Big To meet the customer's needs,

data, I.T,

(Crt6-02) advanced equipment is used.
Environmentally sustainable materials are being manufactured due to technical advancements.
Iftikhar and Khan (2020); Hofmann and Rutschmann (2018);

Ralston and Blackhurst (2020)

\section{Research Methodology}

The SWARA approach calculates the weights of variables to help the sustainable supply chain built on their sustainable enactment. The stepwise assessment ratio analysis (SWARA) approach assists decision-makers in decreasing ambiguity and biasness. It is the most appropriate tool for making high-level decisions (Zavadskas et al. 2018). Experts play a critical part in the method's measurement and calculation of weights and measures of this method. An expert evaluates parameters based on his or her expertise, information, and experience. The critical component of this approach is the ability to estimate experts' opinions on the significance ratio of the criterion for weight determination. The ability to exclude irrelevant parameters and factors is the key benefit of this approach. When experts compare the parameters, they may conclude the standards are irrelevant in the established model of research intention due to the significant difference (Zolfani and Saparauskas 2013). SWARA differs from other multi-criteria decision methods such as TOPSIS, fuzzy, ANP, AHP, and others. It allows business practitioners to pick up their main concerns based on current environmental and economic conditions (Gandhi et al. 2016). Thus, in the context of COVID-19, the SWARA technique will help analyze the factors. As a result, compared to AHP, this method has fewer comparisons, making it easier for decision-makers to use. SWARA is the most appropriate method to use for this research because the goal of this study is to identify factors that will improve the sustainable supply chain in a pandemic situation. The following section discusses this method in detail.

\subsection{SWARA method (Stepwise weight assessment ratio analysis)}

This approach brings professional input into the creation of such critical projects. As a result, the SWARA approach has been considered a key instrument in the decision-making and policy-making processes at the highest ranks of businesses and organizations Professionals are requested to rate each weight's superiority and rank it in order of choice based on their understanding, skills, and experience. On a 9-point scale, the most critical parameter is ranked first, and the last imperative benchmark is ranked nine. This approach has been used to make decisions in various fields, including sustainability, green provider, site, solar plant, service quality, car, and several others (Prajapati et al. 2019; Vafaeipour et al. 2014). The procedures for calculating weights are shown below.

Step 01. Organize requirements according to experts' recommendations. According to expert opinion, the criteria are arranged in descending order.

Step 2. Determine the proportional weighting of parameters. Experts demonstrate the related significance of the jth criterion under the previous (j1) criterion by comparing the importance of the average value (sj) ratio from the second criterion forward.

Step 3. Computation of Co-efficient kj:

$$
k j= \begin{cases}1 & j=1 \\ s j=1 & j>1\end{cases}
$$

Step 4. The degree to the recalculated weight of wj:

$$
w j= \begin{cases}1 & j=1 \\ \frac{x j-1}{k j} & j>1\end{cases}
$$

Step 5. Computation of the final weights, where qj is the relative weight of the wth criterion and $\mathrm{n}$ is the number of measures.

Step 6. Synthesis

The weight obtained $(\mathrm{Wj})$ is multiplied by the individual sub-criteria weights to get the global weights of variables.

\subsection{Sources of data collection}

Data collected from supply chain specialists having almost 10 years of practice. Supply chain experts (distribution managers, manufacturing managers, shipment officers, suppliers, retailers, and procurement administrators) from various FMCGs companies account for data collection.

The data collected using a prescribed survey sent via e-mail between April 12 and May 9, 2021. Finally, for this analysis, follow the structure of (Ikram et al. 2020) 18 experts from various fields, backgrounds, and geographical locations were selected. Table 2 represents the demographic profile of the professionals. 
Table 2. Demographic information

\begin{tabular}{|c|c|c|}
\hline Variable name & Number & Organization \\
\hline \multicolumn{3}{|l|}{ Gender } \\
\hline Female & 04 & \\
\hline Male & 14 & \\
\hline \multicolumn{3}{|l|}{ Age } \\
\hline $31-40$ years & 12 & \\
\hline $41-50$ years & 06 & \\
\hline \multicolumn{3}{|l|}{ Qualification } \\
\hline Bachelor & 03 & \\
\hline Post-graduation & 15 & \\
\hline \multicolumn{3}{|l|}{ Working experience } \\
\hline Less than ten years & 0 & \\
\hline $10-12$ years & 11 & \\
\hline $12-15$ years & 7 & \\
\hline \multicolumn{3}{|l|}{ Expertise } \\
\hline Shipment exective & 02 & Coca-Cola \\
\hline Production managers & 03 & Engro Foods \\
\hline Procurement (Manager) & 02 & Unilever \\
\hline Sales (Manager) & 03 & Nestle \\
\hline Suppliers & 04 & Reckitt Benckiser \\
\hline Retailor & 02 & Tobacco Company \\
\hline Distributors & 02 & National Foods \\
\hline
\end{tabular}

\subsection{Using SWARA to identify the factors and calculate the weights}

The literature review categorizes 19 critical considerations that experts have further confirmed. The current research explores a method seen in Figure 02 for determining essential elements responsible for increasing the survival of the supply chain's sustainability and promoting the relations of buyer and supplier to face research questions.

Priorities are computed using the practices previously mentioned. On the reference chart, each professional is requested to have a weightage (Table A2 in Appendix). In table 3, the measurement of G.M (geometric mean) of the expert panel's preferences for the key groups is estimated. In the same way, in table 4, the classification priorities are calculated. Appendix A shows an example of Expert 1 inputs for key and decision criteria for global weight measurement (Table A3, Table A4). The parameters and decision criteria are arranged in Table 5 based on their relative weights.

\section{Results And Discussion}

The significance value determined using the SWARA method has been used to rate the significant features for promoting the viability of supply chain' sustainability relying on supplier-buyer associations in this evaluation. This research encourages decision-makers, stakeholders, and firms to manage the relations of suppliers and buyers during COVID-19 to overcome supply chain issues. Table 3 shows that the COVID-19 context and the viability of supply chain network (Crt4) are the relevant criteria for developing the supply chain's sustainability. Experts choose Crt4 >Crt5 > Crt6 $>$ Crt1 >Crt3>Crt2 as the order of the parameters. Table 5 shows how their comprehensive weights estimate the various parameters for the viability of supply-Chain network (Crt4), which holds the maximum weight (0.4546). Beer (1981) presented the model of the viable system, which identifies viability as the organization's capacity to satisfy the demands of living in a dynamic atmosphere. The potential of supply chains to navigate and operate in a disruptive atmosphere by redesigning and restructuring mechanisms to develop long-term implications is considered viability. This pandemic has influenced all sectors and the market, requiring supply chain professionals to relocate to a different decision-making framework (Ivanov 2020).

Table 3: main criteria, estimated weightage, and rank in order 


$\begin{array}{lll}\text { Criteria } & \text { Computed weight } & \text { Rank in order } \\ \begin{array}{l}\text { Crt1- Supply chain performance in uncertain conditions } \\ \text { Crt2- Configuration of Supply-Chain (CSC) }\end{array} & 0.07992123 & 4 \\ \begin{array}{l}\text { Crt3- governance of supply chain } \\ \text { Crt4- Viability of network of supply chain }\end{array} & 0.02750119 & 6 \\ \text { Crt5- Collaborations of supply chain } & 0.04689168 & 5 \\ \text { Crt6- Digital data-driven SC } & 0.45465483 & 1 \\ & & 2 \\ & 0.24428464 & 3\end{array}$

Table 3 shows the weightage of main criteria and order for the main criteria. Thus, the research illustrates during the unpredictable circumstance of COVID-19 pandemics, supply chains' instability resilience must be sustainable in surviving, stabilizing, and escaping market crashes. The efficacy of supply chains, which integrate virtual networks in dynamic structures, is frequently considered (Aubin 1991). The viability of supply chains might refer to their long-term market mobility in economies. The supply chains' sustainability in pandemics goes beyond their efficiency, earnings, or sales, and their concern for long-term viability has prompted risk management behavior (Keogh 2020). Resiliency (Crt4-1), Robustness (Crt4-2), and Stability (Crt4-3) are the three sub-parameters of this primary criterion (Crt4). According to the findings, resiliency and sustainability are the two most important considerations, with global weights of (0.2459) and (0.1341), respectively. All of these variables must be prioritized to improve sustainable supply chain survivability. Supply-Chain Viability (Crt4) is a complex system with structural dynamics driven by attitude, while resiliency is driven by instability. Without explicitly considering efficiency, the supreme required asset of a supply system is stability.

The supply chain must be stable to achieve resiliency (Ivanov and Dolgui 2019). COVID-19 has opened the way for supply chains to pursue new insights on resiliency and viability processes. Various behaviors are shown to transform buyer-supplier relationships to build sustainable survival. Supply chains are often reliant on the corporation or buyer-supplier association for their survival. The collaboration of supply chain connection has the second-highest weight (.2442) among the key parameters. The supply chain partnership works as a method for reducing the impact of the bullwhip effect. As a result, the supply chain must create an inclusive and vigorous configuration to meet consumer demands, assisted by cooperation among supply chain members. The critical criterion of collaboration of Supply chain (Crt5) is divided into four sub-categories: collaborative strategy, replenishment and forecasting (Crt5-1), interior coordination (Crt5-2), supply chain co-creation (Crt5-3), and competitive edge (Crt5-4).

The sub-criteria is the measurement items for the main criteria. Each main criteria has three to four sub-criteria. However, experts are requested to choose and gave weightage according to their priorities. The main criteria and sub-criteria support each other in calculating weightage that will be the base of ranking. Based on the estimated scale, one would be able to choose the criteria for decision. So, the main criteria, sub-criteria and weightage are mention in the table 4.

Table 4: Sub-criteria weightage 


\begin{tabular}{lll} 
Criteria & Sub-criteria & Weightage \\
\hline Crt1- Supply chain performance in uncertain conditions & Crt1-1 & 0.30102 \\
\hline & Crt1-2 & 0.53621 \\
\cline { 2 - 2 } Crt2- Configuration of Supply-Chain (CSC) & Crt1-3 & 0.16196 \\
\hline Crt3- governance of supply chain & Crt2-2 & 0.17770 \\
\hline Crt2-3 & 0.52359 \\
\hline Crt4- Viability of network of supply chain & Crt3-1 & 0.29820 \\
\hline Crt3-2 & 0.546048 \\
\hline Crt3- Digital data-driven SC & Crt4-1 & 0.29429 \\
\hline Crt5- Collaborations of supply chain & Crt4-2 & 0.54096 \\
\hline Crt4-3 & 0.29493 \\
\hline Crt5-1 & 0.49734 \\
\hline Crt5-2 & 0.14853 \\
\hline Crt5-3 & 0.27117 \\
\hline Crt5-4 & 0.08240 \\
\hline Crt6-1 & 0.64456 \\
\hline Crt6-2 & 0.35519 \\
\hline
\end{tabular}

Table 5 shows that forecasting, preparation, and replenishment in collaboration (Crt5-1) and supply chain co-creation (Crt5-3) having a loading of (0.1216) and (0.0663), accordingly, which demonstrate that all of these considerations are essential in managing the relationship of buyer and supplier and optimizing sustainable supply chains stability. CPFR (Crt5-1) is a market operation that brings together the intelligence of many supply chains to practice forecasting and planning together to improve demand insight and performance ( $\mathrm{Ni}$ and Sun 2018). Basic demand and supply are beyond the bounds of what supply chains are built for, so CPFR can rely on estimating or evaluating demand. The supply chains should start a unique market forecast that assures projection accuracy and adequate supply for the basics that are in high demand. As the COVID-19 spreads to new places, the global and local supply chains must implement mitigation and alternative plans. The companies see sustainability as a competitive opportunity for associating with suppliers (Singhry and Rahman 2019). Supply chain co-creation in supply chains aims to enhance the process and product while making improvements. Data-driven supply chains are meeting consumer needs by delivering essentials goods to shops at their doorsteps. For quarantine, limited-time retail operations, stay-at-home orders, and selfisolation, supply chains adopt just-in-time and order fulfillment distribution solutions. Supply chains are now reducing the number of goods they provide to concentrate on completing orders on schedule and in a clean and sanitary manner. Many companies have implemented same-day or next-day service delivery, with extra employees and tie-ups temporary have also been planned.

\section{Table 5: Overall ranking of criteria and sub-criteria}




\begin{tabular}{|c|c|c|c|c|c|}
\hline Criteria & Relative weight & Sub-criteria & Weightage & Global weight & Rank in order \\
\hline \multirow[t]{3}{*}{ Crt1-Supply chain performance in uncertain conditions } & 0.079921 & Crt1-1 & 0.30102 & 0.0241 & 11 \\
\hline & & Crt1-2 & 0.53621 & 0.0429 & 8 \\
\hline & & Crt1-3 & 0.16196 & 0.0129 & 15 \\
\hline \multirow[t]{3}{*}{ Crt2- Configuration of Supply-Chain (CSC) } & 0.027501 & Crt2-1 & 0.17770 & 0.0049 & 18 \\
\hline & & Crt2-2 & 0.52359 & 0.0144 & 13 \\
\hline & & $\mathrm{Crt} 2-3$ & 0.29820 & 0.0082 & 16 \\
\hline \multirow[t]{3}{*}{ Crt3- governance of supply chain } & 0.046891 & Crt3-1 & 0.16048 & 0.0075 & 17 \\
\hline & & Crt3-2 & 0.54476 & 0.0255 & 10 \\
\hline & & Crt3-3 & 0.29429 & 0.0138 & 14 \\
\hline \multirow[t]{3}{*}{ Crt4-Viability of network of supply chain } & 0.45455 & Crt4-1 & 0.54096 & 0.2459 & 1 \\
\hline & & Crt4-2 & 0.16372 & 0.0744 & 5 \\
\hline & & Crt4-3 & 0.29493 & 0.1341 & 2 \\
\hline \multirow[t]{4}{*}{ Crt5- Collaborations of supply chain } & 0.24428 & Crt5-1 & 0.49734 & 0.1215 & 3 \\
\hline & & Crt5-2 & 0.14853 & 0.0363 & 9 \\
\hline & & Crt5-3 & 0.27117 & 0.0662 & 6 \\
\hline & & Crt5-4 & 0.08240 & 0.0201 & 12 \\
\hline \multirow[t]{2}{*}{ Crt6- Digital data-driven SC } & 0.14256 & Crt6-1 & 0.64456 & 0.0919 & 4 \\
\hline & & Crt6-2 & 0.35519 & 0.0506 & 7 \\
\hline
\end{tabular}

Consumers have enhanced their consumption of health and wellbeing items, products required for virus protection, and protection steps such as masks and gloves due to the terrifying situation around the world. Resource management at the local level must be considered to avoid stock-out conditions and control order fulfillment to balance supply and demand. One of the most important things for businesses to work during a pandemic is their societal success under instability. The coronavirus has introduced a modern work philosophy focused on achieving organizational productivity by flexible working hours and remote work worldwide. This may be a chance for business operations like e-bay, Google, Amazon, and others to contribute to the economy by promoting platforms for job creation and upholding their corporate duty to ensure the welfare of their workers.

\section{Conclusion And Implications}

This research investigates the substantial aspects for attracting the survival of supply chain's sustainability and maintaining the relations of buyer and supplier. There is no single aspect on which the supply chains can depend exclusively on this pandemic. Still, the current focus on market delivery resiliency, data-driven market delivery, stability, order fulfillment strategies, and supplier cooperation could be fruitful. Consumers increasingly adopt contactless or online order solutions due to fear of transmission in public spaces and social distancing, providing the basis for supply chains sustainability to develop in the postCOVID-19 era. This study looks at the prospects for supply chains, the human-machine ratio, and the use of hybrid models and operational processes. This research helps create collaborative, integrated, and supply chain sustainability during and post-COVID-19 scenarios, and companies that neglect excellent customer support' having the risk of losing business and ultimately extinction.

Pandemics seem to be the most critical attribute of market instability. COVID-19 has incorporated a lift-it-up of insubstantiality, but effective means of maintaining supply chains could have changed forever. Supply chains must update their strategic direction to respond to technology changes, social environment, change their business structures, including various networks, to enhance long-term economic and social benefits. The main drivers for fastmoving consumer goods (FMCGs) businesses to succeed and thrive in pre-and post-COVID-19 circumstances are viability, resiliency, order fulfillment/just-intime, stability, data analytics, teamwork, convergence, demand forecasting, and real-time intelligence. Practical, durable supply chains engage distributors and other stakeholders in an inclusive and accountable mechanism that promotes endeavors for fast-moving consumer goods (FMCGs) companies' long-term progress. For fast-moving consumer goods (FMCGs) organization's success, resilient supply chains must be designed across proper demand scheduling, monitoring, distribution network, supplier meetings, supplier cooperation, and predicting the impact of economic and social conditions. Since coronavirus has a long-term effect on supply chains, it's essential to know several shipping methods. The integration of a shipping distribution approach would reduce costs and prioritize a safe inventory stock supply strategy, which will help fast-moving consumer goods (FMCGs) supply chains survive.

There are some limitations of this research. First, a sustainable supply chain is evaluated could be biased due to a panel of experts. To ensure that the findings are robust, a responsive analysis may be used. Additionally, empirical experiments may be used to validate the research. Further, customers were excluded from the expert groups selected for data collection for this study; thus, it would be appropriate to collect data and get consumer details from retailers who acquired goods during the and after the COVID-19 pandemic. So, it may increase the expert group's integrity and support the results of this analysis.

6.1 Managerial/ Practical implication 
COVID-19's long-term psychological, financial, and health consequences remain uncertain. If this condition extends months or further years, the virus's global reaction has altered the supply chain's thought and preparation. The emergence of this pandemic has been affecting many businesses around the world, with major economic outcomes. Travel bans and quarantines have damaged worldwide supply chains and reduced profits due to policies aimed at preventing the transmission of these diseases. There seem to be two aspects of the research used to examine variables that affect sustainable supply chains and buyersupplier connections. First, this study aims to look at the social, economic, and environmental impacts on enterprises to improve the long-term efficacy of sustainable supply chains. Since COVID-19 has long-term consequences on global economies, the study indicates that supply chains must become sustainable to survive and succeed in the long run. In this critical situation, a supply chain that focuses on cooperation with suppliers, resiliency, robustness, and innovative data analytics for value addition is more efficient. These strategies contribute not only to improving operating efficiency in the short term. But also in strengthening their supply chains in the long term to cope with the post-COVID-19 condition. Supply chains in the fast-moving consumer goods industry must adapt to new socio-economic needs to succeed and thrive in the long run. The global atmosphere requires customers to remain at home, retain social distance, and maintain hygiene, resulting in an immediate increase in handling supply chains to meet the demand for necessities. Such as sanitary wipes, gloves, soaps, masks, disinfect devices, immune-boosting drugs, and other products, and where online distribution is not meeting demand, in-store sales should be maintained.

The social responsibilities are also exhausting fast-moving consumer goods managers to improve their supply chains with several problems, such as labor shortages, uncertain competitive pressures, extended working hours for employees, maintaining social distancing across massive crowds, treating visitors' arriving without masks and gloves. If some of these issues are not overcome, it will almost certainly result in business failure shortly. As a result, viable supply chains can cope with such instabilities before and after COVID-19. Supply chains in the fast-moving consumer goods industry must control demand and inventory in the short and long term using advanced technologies such as big data analytics to manage orders based on real-time data and the internet of things (Raut et al. 2019) to mitigate manufacturing losses, plant shutdowns, and economic downturn. To succeed and thrive in a post-pandemic situation, fast-moving consumer goods businesses must find their way to the digital transformation of supply chain practices. The 'new standard' scenario would be more geared toward introducing new products to consumer's preferences.

Second, as the pandemic spreads across the world, living environments, consumer preferences, and behavioral norms shift significantly. The transformation of new supply chain environment for online shopping, click and collect, contactless distribution services, and increased product segment intake. Consumers are stocking up on critical goods for quarantine or staying at home, causing supply chains to run out of stock. As a result, order fulfillment at the customer's doorstep is becoming more attractive to shoppers who want to avoid crowds, long lines, and security concerns. Sustainable supply chains of fast-moving consumer goods companies must adjust strategies accordingly as the social climate and environmental circumstances change in most countries, such as Pakistan and India, where the living process is constrained. Demand forecasting and inventory preparation for order delivery at local levels must be considered for handling stock-out situations until the restricted demanding period ceases and the transfer to a normal living phase begins. Supply chains must carefully monitor government rules on various forms of controls and relaxations. Supply chains must urgently cope with the limited living process when planning for the "new normal." Supply chains of fast-moving consumer goods businesses should concentrate on resiliency and viability in a "modern standard" situation, transitioning into a digital industry to provide social and economic benefits to society and turning into a network platform for positive impact on society. The study has offered fast-moving consumer goods companies with insights into developing new strategies based on changing consumer trends and personality traits that would be successful in post-COVID-19 scenarios, including evolving consumer interest in social media platforms, inventory management, regular sanitization, social distancing, and employee knowledge of sanitation and social safety precautions. To cope with these problems, businesses are spreading workforce awareness activities on health and sanitation through many networking channels. The COVID-19 catalyzes the creation of resilient, secure supply chains that can respond to any crisis. The supply chain's approach to teamwork, resilience, order fulfillment and data mining to survive in COVID-19 pandemics is critical.

\section{Declarations}

Consent to participate: I am free to contact any research people to seek further clarification and information.

Consent to publish: Not applicable.

Authors Contribution: Conceptualization: K.H.; formal statistical analysis: K.H.; Data collection: K.H and M.A.K.; Investigation: K.H.; methodology: K.H.;supervision: Z.JJ. and S.A.; writing final draft: K.H.; review and editing: K.H., Z.JJ., and S.A.

Funding: The study is supported by the National Natural Science Foundation of China; Grant no. (71502073).

Data Availability: The datasets/materials used and analyzed for the present manuscript are available from the corresponding author on reasonable request.

\section{Compliance with ethical standards}

Ethical approval: Not applicable.

Conflicts of Interest: The authors declare no conflict of interest.

\section{References}

Albors-Garrigos, J. 2020. "Barriers and Enablers for Innovation in the Retail Sector: Co-Innovating with the Customer.A Case Study in Grocery Retailing." Journal of Retailing and Consumer Services 55: 102077. 
Alghababsheh, M., and D. Gallear. 2020. "Socially Sustainable Supply Chain Management and Suppliers' Social Performance: The Role of Social Capital." Journal of Business Ethics 163: 125-150. https://doi.org/10.1007/ s10551-018-3993-0.

Araz, O. M., T. M. Choi, D. L. Olson, and F. S. Salman. 2020. "Role of Analytics for Operational Risk Management in the Era of Big Data." Decision. https://doi.org/10.1111/deci.12451.

Ashby, A., M. Leat, and M. Hudson-Smith. 2012. "Making Connections: A Review of Supply Chain Management and Sustainability Literature." Supply Chain Management: An International Journal 17 (5): 497-516.

Aßländer, M. S., J. Roloff, and D. Z. Nayır. 2016. "Suppliers as Stewards? Managing Social Standards in First- and Second-Tier Suppliers." Journal of Business Ethics 139 (4): 661-683.

Aubin, J. P. 1991. Viability Theory. Boston, Basel, Berlin: Birkhäuser.

Badraoui, I., J. G. Van der Vorst, and Y. Boulaksil. 2020. "Horizontal Logistics Collaboration: An Exploratory Study in Morocco's AgriFood Supply Chains." International Journal of Logistics Research and Applications 23 (1): 85-102.

Beer, S. 1981. Brain of the Firm (2nd edn.). John Wiley \& Sons: Chichester.

Blackhurst, J., K. S. Dunn, and C. W. Craighead. 2011. "An Empirically Derived Framework of Global Supply Resiliency." Journal of Business Logistics 32 (4): 374-391.

Blome, C., A. Paulraj, and K. Schuetz. 2014. "Supply Chain Collaboration and Sustainability: A ProDfileviation Analysis." International Journal of Operations and Production Management 34 (5): 639-663.

Bodi-Schubert, A. 2014. “The Conceptual Model of Success in Buyer-Supplier Relationship.” The IMP Journal 8 (1): $31-43$.

Brandenburg, M., T. Gruchmann, and N. Oelze. 2019. "Sustainable Supply Chain Management-a Conceptual Framework and Future Research Perspectives." Sustainability 11 (24): 7239. https://doi.org/10.3390/su11247239.

Busse, C. 2016. "Doing Well by Doing Good? The Self-Interest of Buying Firms and Sustainable Supply Chain Management." Journal of Supply Chain Management 52 (2): 28-47.

Carbone, V., V. Moatti, and V. E. Vinzi. 2012. "Mapping Corporate Responsibility and Sustainable Supply Chains: An Exploratory Perspective." Business Strategy and the Environment 21 (7): 475-494.

Carvalho, H., V. Cruz-Machado, and J. G. Tavares. 2012. "A Mapping Framework for Assessing Supply Chain Resilience." International Journal of Logistics Systems and Management 12 (3): 354-373.

Chakraborty, K., S. Mondal, and K. Mukherjee. 2018. "Developing A Causal Model to Evaluate the Critical Issues in Reverse Supply Chain Implementation." Benchmarking: An International Journal 25 (7): 1992-2017.

Chen, L., X. Zhao, O. Tang, L. Price, S. Zhang, and W. Zhu. 2017. "Supply Chain Collaboration for Sustainability: A Literature Review and Future Research Agenda." International Journal of Production Economics 194: 73-87.

Chi, M., R. Huang, and J. F. George. 2020. "Collaboration in Demand-Driven Supply Chain: Based on A Perspective of Governance and IT-

Business Strategic Alignment." International Journal of Information Management 52: 102062.

Choi, T. M., and S. Guo. 2020. "Is A L'Furneech 'a Good Lunch? The Performance of Zero Wholesale Price-Based Supply-Chain Contracts." European Journal of Operational Research 285 (1): 237-246.

Cohen, M. J. 2020. "Does the COVID-19 Outbreak Mark the Onset of A Sustainable Consumption Transition?" Sustainability: Science, Practice and Policy 16 (1): 1 - 3. https://doi.org/10.1080/15487733.2020.1740472.

Dania, W. A. P., K. Xing, and Y. Amer. 2019. "An Integrated Collaboration Framework for Sustainable Sugar Supply Chains." International Journal of Supply Chain Management 8 (3): 706-717.

Demirel, G., B. L. MacCarthy, D. Ritterskamp, A. R. Champneys, and T. Gross. 2019. "Identifying Dynamical Instabilities in Supply Networks Using Generalized Modeling." Journal of Operations Management 65 (2): 136-159.

Dolgui, A., D. Ivanov, and M. Rozhkov. 2020. “Does the Ripple Effect Influence the Bullwhip Effect? An Integrated Analysis of Structural and Operational Dynamics in the Supply Chain." International Journal of Production Research 58 (5): 1285-1301.

Dubey, R., A. Gunasekaran, T. Papadopoulos, S. J. Childe, K. T. Shibin, and S. F. Wamba. 2017. "Sustainable Supply Chain Management: Framework and Furthe 1130.

Dun \& Bradstreet. 2020. Accessed March 10, 2020. https://foreignpolicy.com/2020/03/04/blindsided-on-the-supply-side/. 
Eggers, J. E., E. Hofman, H. Schiele, and E. Holschbach. 2017. “Identifying the 'Right' Supplier for Module Developments-a Cross-Industrial Case Analysis." International Journal of Innovation Management 21 (3): 1750026.

Feizabadi, J., D. Gligor, and S. Alibakhshi Motlagh. 2019. “The Triple-as Supply Chain Competitive Advantage.” Benchmarking: An International Journal 26 (7): 2286-2317.

Fortune. 2020. Accessed March 10, 2020. https://fortune.com/2020/02/21/fortune-1000-coronavirus-china-supply- chain-impact/.

Gandhi, S., S. K. Mangla, P. Kumar, and D. Kumar. 2016. "A Combined Approach Using AHP and DEMATEL for Evaluating Success Factors in Implementation of Green Supply Chain Management in Indian Manufacturing Industries." International Journal of Logistics Research and Applications 19 (6): $537-561$.

Gereffi, G., and J. Lee. 2016. "Economic and Social Upgrading in Global Value Chains and Industrial Clusters: Why Governance Matters.” Journal of Business Ethics 133 (1): 25-38.

Guan, Z., X. Zhang, M. Zhou, and Y. Dan. 2020. "Demand Information Sharing in Competing Supply Chains with Manufacturer-Provided Service." International Journal of Production Economics 220: 107450.

Harms, D., E. G. Hansen, and S. Schaltegger. 2013. "Strategies in Sustainable Supply Chain Management: An Empirical Investigation of Large German Companies." Corporate Social Responsibility and Environmental Management 20 (4): 205-218.

Hoang, L., G. Blank, and A. Quan-Haase. 2020. "The Winners and the Losers of the Platform Economy: Who Participates?" Information, Communication \& Society 23 (5): 681-700. https://doi.org/10.1080/1369118X.2020. 1720771.

Hofmann, E., and E. Rutschmann. 2018. "Big Data Analytics and Demand Forecasting in Supply Chains: A Conceptual Analysis." The International Journal of Logistics Management 29 (2): 739-766.

Holgado de Frutos, E., J. R. Trapero, and F. Ramos. 2020. "A Literature Review on Operational Decisions Applied to Collaborative Supply Chains." PloS one 15 (3): e0230152.

Hollmann, R. L., L. F. Scavarda, and A. M. T. Thomé. 2015. “Collaborative Planning, Forecasting and Replenishment: A Literature Review." International Journal of Productivity and Performance Management 64 (7): 971-993.

Hosseini, S., D. Ivanov, and A. Dolgui. 2019. "Review of Quantitative Methods for Supply Chain Resilience Analysis." Transportation Research Part E: Logistics and Transportation Review 125: 285-307.

Hughes, D. E., K. A. Richards, R. Calantone, B. Baldus, and R. A. Spreng. 2019. "Driving in-Role and Extra-Role Brand

Performance among Retail Frontline Salespeople: Antecedents and the Moderating Role of Customer Orientation.” Journal of Retailing 95 (2): $130-143$.

Iftikhar, R., and M. S. Khan. 2020. "Social Media Big Data Analytics for Demand Forecasting: Development and Case Implementation of an Innovative Framework." Journal of Global Information Management 28 (1): 103-120.

Ikram, M., Zhang, Q., \& Sroufe, R. (2020). Developing integrated management systems using an AHP-Fuzzy VIKOR approach. Business Strategy and the Environment, 29(6), 2265-2283. https://doi.org/10.1002/bse.2501

Ikram, M., Zhang, Q., Sroufe, R., \& Ferasso, M. (2020). The social dimensions of corporate sustainability: An integrative framework including COVID-19 insights. Sustainability (Switzerland), 12(20), 1-29. https://doi.org/10.3390/su12208747

Ishfaq, R., and N. Bajwa. 2019. "Profitability of Online Order Fulfillment in Multi-Channel Retailing." European Journal of Operational Research 272 (3): $1028-$ 1040 .

Ishfaq, R., and U. Raja. 2018. "Evaluation of Order Fulfillment Options in Retail Supply Chains." Decision Sciences 49 (3): $487-521$.

Ivanov, D. 2020. "Predicting the Impacts of Epidemic Outbreaks on Global Supply Chains: A Simulation-Based Analysis on the Coronavirus Outbreak (COVID19/SARS-CoV-2) Case." Transportation Research Part E: Logistics and Transportation Review 136: 101922.

Ivanov, D., and A. Dolgui. 2019. "Low-Certainty-Need (LCN) Supply Chains: A New Perspective in Managing Disruption Risks and Resilience." International Journal of Production Research 57 (15-16): 5119-5136. https:// doi.org/10.1080/00207543.2018.1521025.

Ivanov, D., and A. Dolgui. 2020. "Viability of Intertwined Supply Networks: Extending the Supply Chain Resilience Angles Towards Survivability. A Position Paper Motivated by COVID-19 Outbreak." International Journal of Production Research 58 (10): 2904-

2915. https://doi.org/10.1080/00207543.2020.1750727.

Ivanov, D., S. Sethi, A. Dolgui, and B. Sokolov. 2018. "A Survey on Control Theory Applications to Operational Systems, Supply Chain Management, and Industry 4.0." Annual Reviews in Control 46: 134-147.

Ivanov, D., B. Sokolov, and J. Kaeschel. 2010. "A Multi-Structural Framework for Adaptive Supply Chain Planning and

Operations Control with Structure Dynamics Considerations." European Journal of Operational Research 200 (2): 409-420.

Page $13 / 17$ 
Karabasevic D, Stanujkic D, Urosevic S, Maksimovic M (2015) Selection of candidates in the mining industry based on the application of the SWARA and the MULTIMOORA methods. Acta Montan Slovaca 20(2):116-124

Keogh, J. G., A. Rejeb, N. Khan, K. Dean, and K. J. Hand. 2020a. n“Dd aFtoaod Supply Chain: Blockchain and GS1 Standards in the Food Chain: A Review of the Possibilities and Challenges." Building the Future of Food Safety Technology 145: 145-178. http://10.1016/B978-0-12-818956-6.00007 5.

KPMG. 2020. COVID-19 Surveillance Challenges. Accessed May 9, 2020. https://home.kpmg/xx/en/blogs/home/ posts/2020/04/surveillance-challengesunder-covid-19.html.

Kudla, N. L., and T. Klaas-Wissing. 2012. "Sustainability in Shipper-Logistics Service Provider Relationships: A Tentative Taxonomy Based on Agency Theory and Stimulus-Response Analysis." Journal of Purchasing and Supply Management 18 (4): 218-231.

Kumar, D. 2019. "Buyer-supplier Relationship Selection for A Sustainable Supply Chain: A Case of the Indian Automobile Industry." International Journal of the Analytic Hierarchy Process 11 (2): 215-227.

Kumar, D., and Z. Rahman. 2016. "Buyer Supplier Relationship and Supply Chain Sustainability: Empirical Study of Indian Automobile Industry." Journal of Cleaner Production 131: 836-848.

Leszczynska, A. 2018. "Sustainable Supply Chain Capabilities - Factors Stimulating the Processes and Organisational Performance." International Journal of Sustainable Economy 10 (3): 263-282.

Li, B., and Y. Jiang. 2019. "Impacts of Returns Policy Under Supplier Encroachment with Risk-Averse Retailer." Journal of Retailing and Consumer Services 47: 104-115.

Li, Y., and C. W. Zobel. 2020. "Exploring Supply Chain Network Resilience in the Presence of the Ripple Effect." International Journal of Production Economics 228: 107693. https://doi.org/10.1016/j.jpe.2020.107693.

Linton, T., and B. Vakil. 2020. “Coronavirus is Proving we Need More Resilient Supply Chains." Harward Business Review, March 5. Accessed March 10, 2020. https://hbr.

Lintukangas, K., J. Hallikas, and A. K. Kähkönen. 2015. "The Role of Green Supply Management in the Development of Sustainable Supply Chain.” Corporate Social Responsibility and Environmental Management 22 (6): 321-333.

Liu, C. L., and M. Y. Lee. 2018. "Integration, Supply Chain Resilience, and Service Performance in Third-Party Logistics Providers." The International Journal of Logistics Management 29 (1): 5-21.

Madsen, S. M., and A. Petermans. 2020. "Exploring the System of Digitised Retail Design-Flattening the Ontology." Journal of Retailing and Consumer Services 54: 102053.

Marques, L. 2019. "Sustainable Supply Network Management: A Systematic Literature Review from A Knowledge Perspective." International Journal of Productivity and Performance Management 68 (6): 1164-1190.

McKinsey. 2020. McKinsey. Accessed May 9, 2020. COVID-19: Implications for Business. https://www.mckinsey.com/ business-functions/risk/ourinsights/covid-19-implications-for-business.

Merminod, N., and G. Paché. 2011. "Supply Management and Corporate Social Responsibility: The Challenge of Global Chain Traceability." Journal on Chain and Network Science 11 (3): 213-222.

Nakano, M., and K. Matsuyama. 2020. "Internal Supply Chain Structure Design: A Multiple Case Study of Japanese Manufacturers." International Journal of Logistics Research and Applications 1-23. https://doi.org/10.1080/ 13675567.2020.1726305.

Nazam, M., M. Hashim, M. A. Randhawa, and A. Maqbool. 2020. "Modeling the Barriers of Sustainable Supply Chain Practices: A Pakistani Perspective." Advances in Intelligent Systems and Computing 1002 (2): 348-364.

Ni, W., and H. Sun. 2018. "A Contingent Perspective on the Synergistic Effect of Governance Mechanisms on Sustainable Supply Chain." Supply Chain Management: An International Journal 23 (3): 153-170.

Pakdeechoho, N., and V. Sukhotu. 2018. "Sustainable Supply Chain Collaboration: Incentives in Emerging Economies." Journal of Manufacturing Technology Management 29 (2): 273-294.

Panahifar, F., and S. Shokouhyar. 2019. "An Interpretive Structural Modelling of Enablers for Collaborative Planning, Forecasting and Replenishment Implementation in High-Tech Industries." International Journal of Information and Decision Sciences 11 (1): 55-72.

Pankowska, M. 2019. "Information Technology Outsourcing Chain: Literature Review and Implications for Development of Distributed Coordination." Sustainability 11 (5): 1460. 
Patel, A. B., and T. N. Desai. 2019. "A Systematic Review and Meta-Analysis of Recent Developments in Sustainable Supply Chain Management." International Journal of Logistics Research and Applications 22 (4): 349-370.

Pavlov, A., D. Ivanov, D. Pavlov, and A. Slinko. 2019. "Optimization of Network Redundancy and Contingency Planning in Sustainable and Resilient Supply Chain Resource Management Under Conditions of Structural Dynamics." Annals of Operations Research 1-30. https://doi.org/10.1007/s10479-019-03182-6.

Prajapati, H., R. Kant, and R. Shankar. 2019. "Prioritizing the Solutions of Reverse Logistics Implementation to Mitigate its Barriers: A Hybrid Modified SWARA and WASPAS Approach." Journal of Cleaner Production 240: 118219.

Prince, M., L. Kwak, and C. V. Priporas. 2019. "The Diogenes Effect in Retail Buyer Information Processing." Journal of Retailing and Consumer Services 49: 164-172.

RAI. 2020. Retailer Association of India. Accessed May 13, 2020 rai.net.in: http://www.businessworld.in/article/RAl- Survey-Results-Impact-of-Covid-19-onIndian-Retailers/07-04-2020-188501/.

Ralston, P., and J. Blackhurst. 2020. "Industry 4.0 and Resilience in the Supply Chain: A Driver of Capability Enhancement or Capability Loss?" International Journal of Production Research 58: 1-14. https://doi.org/10. 1080/00207543.2020.1736724.

Rao, S., S. E. Griaffinsd, T. J. Goldsby. 2011. "Failure to Deliver? Linking Online Order Fulfillment Glitches with Future Purchase Behavior." Journal of Operations Management 29 (7-8): 692-703.

Raut, R. D., S. K. Mangla, V. S. Narwane, B. B. Gardas, P. Priyadarshinee, and B. E. Narkhede. 2019. “Linking Big Data Analytics and Operational Sustainability Practices for Sustainable Business Management." Journal of Cleaner Production 224: 10-24.

Reinecke, J., S. Manning, and O. Von Hagen. 2012. "The Emergence of A Standards Market: Multiplicity of Sustainability Standards in the Global Coffee Industry." Organization Studies 33 (5-6): 791-814.

Reuter, C., K. A. I. Foerstl, E. V. I. Hartmann, and C. Blome. 2010. "Sustainable Global Supplier Management: The Role of Dynamic Capabilities in Achieving Competitive Advantage." Journal of Supply Chain Management 46 (2): 45-63.

Roy, A., S. S. Sana, and K. Chaudhuri. 2018. "Optimal Pricing of Competing Retailers Under Uncertain Demand-A Two Layer Supply Chain Model." Annals of Operations Research 260 (1-2): 481-500.

Roy, V., B. S. Silvestre, and S. Singh. 2020. "Reactive and Proactive Pathways to Sustainable Apparel Supply Chains: Manufacturer's Perspective on Stakeholder Salience and Organizational Learning Toward Responsible Management." International Journal of Production Economics 227 : 107672.

Sarkis, J., M. J. Cohen, P. Dewick, and P. Schröder. 2020. “A Brave New World: Lessons from the COVID-19 Pandemic for Transitioning to Sustainable Supply and Production." Resources, Conservation and Recycling 159: 104894.

Sauer, P. C., and S. Seuring. 2017. "Sustainable Supply Chain Management for Minerals.” Journal of Cleaner Production 151: $235-249$.

Simchi-Levi, D., H. Wang, and Y. Wei. 2018. "Increasing Supply Chain Robustness Through Process Flexibility and Inventory." Production and Operations Management 27 (8): 1476-1491.

Singhry, H. B., and A. A. Rahman. 2019. "Enhancing Supply Chain Performance Through Collaborative Planning, Forecasting, and Replenishment." Business Process Management Journal 25 (4): 625-646.

Tachizawa, E. M., and C. Y. Wong. 2014. "Towards A Theory of Multi-Tier Sustainable Supply Chains: A Systematic Literature Review." Supply Chain Management: An International Journal 19 (5/6): 643-663.

Thakur, V., and S. K. Mangla. 2019. "Change Management for Sustainability: Evaluating the Role of Human, Operational and Technological Factors in Leading Indian Firms in Home Appliances Sector." Journal of Cleaner Production 213: 847-862.

Thiagarajan, K. (2021). Why is India having a covid-19 surge? BMJ (Clinical Research Ed.), 373, n1124. https://doi.org/10.1136/bmj.n1124

Tidy, M., X. Wang, and M. Hall. 2016. "The Role of Supplier Relationship Management in Reducing Greenhouse Gas Emissions from Food Supply Chains: Supplier Engagement in the U.K. Supermarket Sector." Journal of Cleaner Production 112: 3294-3305.

Touboulic, A., D. Chicksand, and H. Walker. 2014. "Managing Imbalanced Supply Chain Relationships for Sustainability: A Power Perspective." Decision Sciences 45 (4): 577-619.

Touboulic, A., and H. Walker. 2015. "Love me, Love me not: A Nuanced View on Collaboration in Sustainable Supply Chains." Journal of Purchasing and Supply Management 21 (3): 178-191.

Vafaeipour, M., S. H. Zolfani, M. H. M. Varzandeh, A. Derakhti, and M. K. Eshkalag. 2014. "Assessment of Regions

Priority for Implementation of Solar Projects in Iran: New Application of A Hybrid Multi-Criteria Decision Making Approach." Energy Conversion and Management 86: 653-663. 
Wang, C., Z. Cheng, X. G. Yue, and M. McAleer. 2020. "Risk Management of COVID-19 by Universities in China." Journal of Risk and Financial Management 13 (2): 36 .

Wang, H., Z. Jiang, H. Zhang, Y. Wang, Y. Yang, and Y. Li. 2019. "An Integrated MCDM Approach Considering Demands-Matching for Reverse Logistics." Journal of Cleaner Production 208: 199-210.

Wankmüller, C., and G. Reiner. 2020. “Coordination, Cooperation and Collaboration in Relief Supply Chain Management." Journal of Business Economics 90 (2): $239-276$.

Wilhelm, M. ., C. Blome, V. Bhakoo, and A. Paulraj. 2016. "Sustainability in Multi-Tier Supply Chains: Understanding the Double Agency Role of the First-Tier Supplier." Journal of Operations Management 41: 42-60.

World Trade Organization. 2020. "Trade Set to Plunge as COVID-19 Pandemic Upends Global Economy.” Press Release, April 8. https://www.wto.org/english/news_e/pres20_e/pr855_e.htm.

Wu, K. J., M. L. Tseng, A. S. Chiu, and M. K. Lim. 2017. "Achieving Competitive Advantage Through Supply Chain Agility Under Uncertainty: A Novel MultiCriteria Decision-Making Structure." International Journal of Production Economics 190: 96-107.

Yawar, S. A., and S. Seuring. 2017. "Management of Social Issues in Supply Chains: A Literature Review Exploring Social Issues, Actions and Performance Outcomes." Journal of Business Ethics 141 (3): 621-643.

Zavadskas, E. K., Ž Stević, I. Tanackov, and O. Prentkovskis. 2018. "A Novel Multicriteria Approach-Rough Step-Wise Weight Assessment Ratio Analysis Method (R-SWARA) and its Application in Logistics." Studies in Informatics and Control 27 (1): 97-106.

Zolfani, S. H., and J. Saparauskas. 2013. "New Application of SWARA Method in Prioritizing Sustainability Assessment Indicators of Energy System." Engineering Economics 24 (5): 408-414.

\section{Figures}

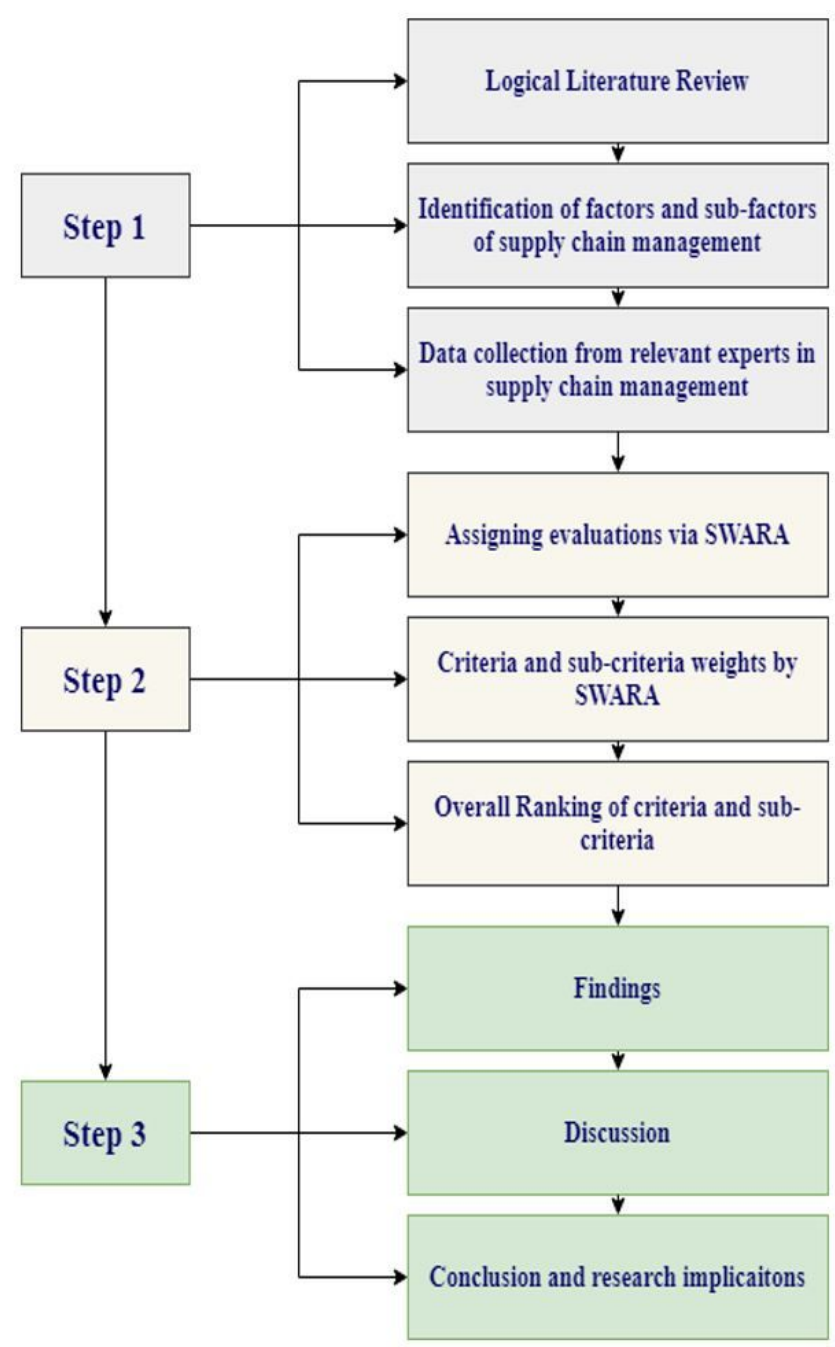

Figure 1 
Research framework

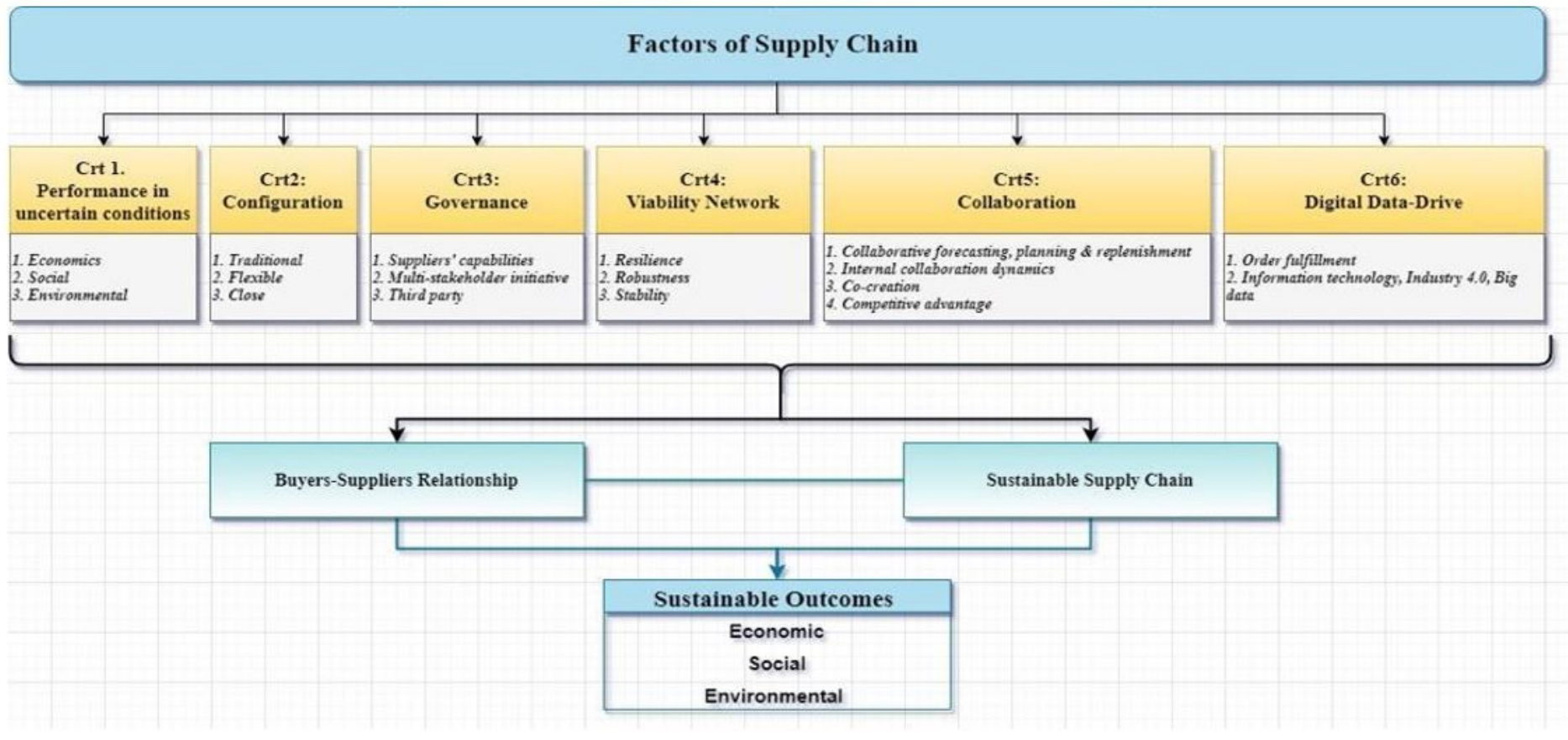

Figure 2

Conceptual framework of sustainablesupply chains in post-COVID-19 